\title{
PENGARUH PEKERJAAN RUMAH DAN MINAT BELAJAR AKUNTANSI TERHADAP PRESTASI BELAJAR AKUNTANSI
}

\section{THE EFFECT OF HOMEWORK AND ACCOUNTING STUDY INTEREST TOWARD ACCOUNTING STUDY ACHIEVEMENT}

\author{
Oleh: \\ $\underline{\text { Muji Mungintoro }}$ \\ Prodi Pendidikan Akuntansi Universitas Negeri Yogyakarta \\ ngintoro@gmail.com \\ Diana Rahmawati \\ Staf Pengajar Jurusan Pendidikan Akuntansi Universitas Negeri Yogyakarta
}

\begin{abstract}
Abstrak
Penelitian ini bertujuan untuk mengetahui pengaruh Pekerjaan Rumah dan Minat Belajar Akuntansi secara bersama-sama terhadap Prestasi Belajar Akuntansi Siswa Kelas X Akuntansi SMK Negeri 7 Yogyakarta Tahun Ajaran 2015/2016. Populasi penelitian ini adalah 96 siswa kelas X Akuntansi SMK Negeri 7 Yogyakarta Tahun Ajaran 2015/2016 yang sekaligus sebagai sampel. Teknik pengumpulan data menggunakan kuesioner dan dokumentasi. Uji validitas dan reliabilitas instrumen dilakukan pada 31 siswa kelas X Akuntansi 1 SMK Negeri 1 Yogyakarta. Uji prasyarat analisis menggunakan uji linieritas dan multikolinieritas.Uji hipotesis terdiri dari regresi sederhana dan regresi ganda. Hasil penelitian terdapat pengaruh positif dan signifikan Pekerjaan Rumah dan Minat Belajar Akuntansi secara bersama-sama terhadap Prestasi Belajar Akuntansi Siswa Kelas X Akuntansi SMK Negeri 7 Yogyakarta Tahun Ajaran 2015/2016 dengan $R_{y(1,2)}=0,423 ; R_{y(1,2)}^{2}=0,179 ; F_{\text {hitung }}=$ $10,144>\mathrm{F}_{\text {tabel }}=3,09$, sumbangan efektif sebesar $17,9 \%$.
\end{abstract}

Kata kunci: Prestasi Belajar Akuntansi,Pekerjaan Rumah, Minat Belajar Akuntansi

\section{Abstract}

This research aims to know the effect of Homework and Accountin Study Interest together toward the Accounting Study Achievement Students Grade X at SMK Negeri 7 Yogyakarta Academic Year 2015/2016. Population in this research is Accounting students grade X of SMK Negeri 7 Yogyakarta Year 2015/2016 in total of 96 students, they are also as sample. Data collection techniques used were questionnaires and documentation. Instrument validity and reliability test was conducted to 31 Accounting 1 students grade X SMK Negeri 1 Yogyakarta. Prerequisite test analysis used were linearity and multicolinearity test. Hypothesis test were consisted of simple regression and multiple regression. The research result is there are positive and significant effect Homework and Accounting Study Interest toward the Accounting Study Achievement with $R_{y(1,2)}=0,42 ; \mathrm{R}_{\mathrm{y}(1,2)}^{2}=0,179 ; F_{\text {hitung }}$ is $10,144>F_{\text {tabel }}$ is 3,09, effective contribution amounting to $17,9 \%$.

Keywords: Accounting Study Achievement, Homework, Accounting Study Interest

\section{PENDAHULUAN}

Era globalisasi menuntut sumber daya manusia untuk memiliki kemampuan agar dapat bersaing di dunia internasional. Sumber daya manusia yang mempunyai kemampuan untuk bersaing di dunia internasional tentu tidak begitu saja ada tetapi membutuhkan banyak hal yang berperan dalam proses pembentukan sumber daya manusia tersebut. Salah satu hal yang berperan besar dalam membentuk sumber daya manusia menjadi sumber daya yang handal, cerdas, mempunyai karakter dan mampu bersaing di dunia internasional 
adalah melalui pendidikan. Pada hakikatnya, pendidikan bagi manusia itu sendiri berlangsung sepanjang hayat sejak dia dilahirkan sampai dia meninggal dunia. Pendidikan adalah suatu usaha yang dilakukan secara sadar dan sengaja untuk mengubah tingkah laku manusia baik secara individu maupun kelompok untuk mendewasakan manusia melalui upaya pengajaran dan pelatihan (Sugihartono dkk, 2012: 3).

Pendidikan dilaksanakan melalui tiga jalur yaitu pendidikan formal, pendidikan nonformal, dan pendidikan informal. Jalur pendidikan formal merupakan pendidikan sistem persekolahan. Pendidikan formal terdiri atas tiga jenjang yaitu pendidikan dasar, pendidikan menengah, dan pendidikan tinggi.Pendidikan formal dalam hal ini diadakan oleh lembaga yang bernama sekolah. Sekolah merupakan tempat siswa untuk menuntut ilmu dan pengetahuan yang akan berguna bagi kehidupannya di masa yang akan datang. Pentingnya pendidikan di Indonesia ditandai dengan adanya program wajib belajar 12 tahun.

Adanya program wajib belajar 12 tahun ini, maka siswa minimal harus menyelesaikan pendidikannya pada jenjang pendidikan menengah. Jenjang pendidikan menengah disini adalah setingkat SMA/SMK/MA. Pada jenjang pendidikan menengah ini sendiri, salah satu mata pelajaran yang diajarkan adalah akuntansi.

Akuntansi termasuk rumpun ilmu sosial dan akuntansi akan menghasilkan informasi keuangan yang digunakan diberbagai lembaga dan instansi seperti perusahaan dan pemerintahan. Akuntansi merupakan salah satu bidang ilmu yang pada saat ini banyak dibutuhkan dalam dunia kerja. American Institute of Certified Public Accountant
(1953) memberikan definisi mengenai akuntansi sebagai "seni (art) mencatat, mengklasifikasikan dan meringkas transaksi atau peristiwa yang dilakukan sedemikian rupa dalam bentuk uang, atau paling tidak memiliki sifat keuangan dan mengintepretasikan hasilnya". Mata pelajaran akuntansi pada saat ini sudah diajarkan pada tingkat Sekolah Menengah Umum dan Sekolah Menengah Kejuruan.

Salah satu sekolah yang mengajarkan mata pelajaran akuntansi adalah Sekolah Menengah Kejuruan (SMK) Negeri 7 Yogyakarta. SMK Negeri 7 Yogyakarta terletak di Jalan Gowongan Kidul JT III/416 Yogyakarta. Sekolah ini memiliki 5 kompetensi keahlian yaitu Multimedia, Usaha Perjalanan Wisata, Administrasi Perkantoran, Akuntansi, dan Pemasaran. Kompetensi keahlian akuntansi di sekolah ini mempunyai 9 kelas yang terdiri dari 3 kelas di setiap jenjang kelas X, XI dan kelas XII.

Semua sekolah termasuk SMK Negeri 7 Yogyakarta tentu bertujuan untuk dapat menyelenggarakan suatu pendidikan yang baik dan berhasil mencetak lulusan yang berkualitas. Keberhasilan sekolah dalam menyelenggarakan pendidikan dapat dilihat dari berbagai hal, salah satunya adalah dalam hal prestasi belajar yang diperoleh oleh siswa.

Prestasi belajar adalah suatu bukti keberhasilan belajar atau kemampuan seorang siswa dalam melakukan kegiatan belajarnya sesuai dengan bobot yang dicapainya. Prestasi belajar merupakan hasil yang telah dicapai setelah siswa mendapat pembelajaran dalam kurun waktu tertentu. Prestasi belajar seorang siswa dapat menjadi gambaran berhasil tidaknya suatu proses pembelajaran yang telah dilakukan. Prestasi 
belajar dipengaruhi oleh proses belajar siswa yang akan menentukan tingkat prestasi belajar siswa.

Prestasi belajar secara garis besar dipengaruhi oleh dua faktor, yaitu faktor internal dan faktor eksternal. Faktor-faktor internal yang berasal dari dalam diri siswa meliputi: faktor jasmaniah (terdiri dari faktor kesehatan dan cacat tubuh), faktor psikologi (terdiri atas intelegensi, perhatian, minat, bakat, motivasi, persepsi, kematangan dan kesiapan) dan faktor kelelahan. Sedangkan faktor eksternal yang berasal dari luar diri siswa meliputi: faktor keluarga yaitu cara orang tua mendidik, relasi antar anggota keluarga, suasana rumah, keadaan ekonomi keluarga, pengertian orang tua, latar belakang kebudayaan, faktor sekolah yaitu metode mengajar, kurikulum, hubungan guru dengan siswa, hubungan siswa dengan siswa, disiplin sekolah, alat pelajaran, waktu sekolah, keadaan gedung, metode belajar dan tugas rumah; faktor masyarakat yaitu kegiatan siswa dalam masyarakat, media, teman bergaul, dan bentuk kehidupan masyarakat.

Salah satu faktor eksternal yang mempengaruhi prestasi belajar siswa adalah pemberian tugas rumah atau Pekerjaan Rumah (PR). Menurut Muijs, dkk (2008: 150) "Pekerjaan rumah dapat didefinisikan sebagai kegiatan di luar kelas yang merupakan perluasan dari tugas di kelas". PR dapat diindividualisasikan atau diberikan kepada seluruh kelas. Pekerjaan Rumah merupakan salah satu aspek mengajar yang paling luas digunakan oleh guru. Disisi lain, siswa seringkali menganggap Pekerjaan Rumah sebagai beban mereka. Pekerjaan Rumah dapat dirancang dengan maksud meningkatkan prestasi belajar siswa, hal ini dikarenakan dengan pemberian PR maka intensitas belajar siswa akan meningkat dan tingkat penguasaan materi siswa bertambah dengan diharuskannya siswa untuk mengerjakan tugas yang telah diberikan oleh guru. Pemberian pekerjaan rumah pada akhirnya bisa meningkatkan prestasi belajar siswa.

Faktor internal yang berpengaruh pada prestasi belajar salah satunya adalah minat belajar. "Minat Belajar merupakan keinginan yang datang dari hati nurani untuk ikut serta dalam kegiatan belajar" (Suprijanto, 2007: 25). Dalam proses belajar, minat memegang peranan penting bagi prestasi belajar yang akan diperoleh siswa. Seorang siswa akan memperhatikan apa yang diterangkan oleh guru dan mengerjakan tugas yang diberikan jika dia mempunyai minat untuk belajar pada mata pelajaran tertentu. "Minat belajar yang besar cenderung menghasilkan prestasi yang tinggi, sebaliknya minat belajar kurang akan menghasilkan prestasi yang rendah" (Dalyono, 2005: 122). Minat belajar antara siswa yang satu dengan siswa yang lainnya belum tentu sama terhadap satu pelajaran tertentu.

Salah satu cara yang digunakan untuk menentukan prestasi belajar seorang siswa adalah dengan menggunakan test baik tes tertulis maupun tes lisan dan memberikan nilai yang diperoleh oleh siswa. Penilaian hasil belajar di sekolah biasanya dilakukan dengan test baik pada saat ulangan harian, ujian tengah semester maupun ujian akhir serta pemberian tugas oleh guru. Dari penilaian tersebut, sekolah menetapkan standar nilai yang harus dicapai oleh peserta didik.

Prestasi belajar di SMK 7 Yogyakarta didasarkan pada Kriteria Ketuntasan Minimum (KKM). SMK N 7 Yogyakarta 
menerapkan nilai Kriteria Ketuntasan Minimal (KKM) sebesar 75. Prestasi belajar siswa dikatakan baik apabila jumlah siswa yang telah mencapai Kriteria Ketuntasan Minimal (KKM) sebesar $\geq 75 \%$ dari jumlah siswa. Berdasarkan data nilai Ujian Tengah Semester Gasal tahun Ajaran 2015/2016 yang didapatkan dari guru akuntansi, diketahui bahwa Prestasi Belajar Akuntansi siswa masih rendah. Pada kelas X Akuntansi 1 didapatkan data mengenai Prestasi Belajar Akuntansi siswa, dimana dari total 32 siswa yang ada di kelas, terdapat 15 siswa atau $46,88 \%$ yang belum mencapai nilai KKM dan hanya 17 siswa atau 53,12\% yang telah mencapai KKM.

Berdasarkan observasi yang dilakukan di dalam kelas X Akuntansi 1 pada tanggal 16 November 2015 didapatkan data mengenai Pemberian Pekerjaan Rumah oleh guru yaitu Pemberian Pekerjaan Rumah (PR) oleh guru dilakukan disetiap akhir pertemuan. Pemberian Pekerjaan Rumah oleh guru disesuaikan dengan materi yang telah dipelajari oleh siswa. Guru meminta siswa untuk mengerjakan soal latihan yang seharusnya dikerjakan di dalam kelas tetapi dikerjakan di rumah sebagai PR apabila siswa belum selesai mengerjakan. Selain melanjutkan tugas di kelas sebagai PR, guru juga memberikan tugas tambahan dengan intesitas yang cukup rutin pada setiap kompetensi yang dipelajari. Guru memberikan nilai untuk Pekerjaan Rumah siswa. Tujuan Pemberian Pekerjaan Rumah oleh guru ini adalah agar siswa belajar kembali mengenai materi yang telah dipelajari di dalam kelas sehingga pemahaman siswa semakin baik. Jika siswa belajar kembali diharapkan nantinya prestasi belajar yang didapatkannya akan tinggi.Masalah yang ada berkaitan dengan
Pemberian Pekerjaan Rumah oleh guru diantaranya adalah siswa yang masih kesulitan mengerjakan beberapa PR yang diberikan, belum selesainya PR yang dikerjakan sehingga PR dikerjakan ulang di kelas, dan tidak semua siswa mengerjakan tugas Pekerjaan Rumah yang diberikan oleh guru yaitu sebanyak $15,6 \%$ dari jumlah 32 siswa tidak mengerjakan PR.

Berkaitan dengan Minat Belajar Akuntansi siswa, masalah yang ada pada saat proses pembelajaran yang ditemukan berdasarkan observasi di kelas X Akuntansi 1 diantaranya adalah Minat Belajar Akuntansi Siswa yang masih kurang. Hal ini ditunjukkan dengan tingkat keaktifan siswa dalam mengikuti kegiatan belajar mengajar di kelas yang masih rendah, tidak semua siswa aktif dalam mengikuti kegiatan belajar mengajar, hanya beberapa siswa yang aktif dalam bertanya dan menjawab pertanyaan. Selain itu, pada saat pembahasan soal terdapat siswa yang berbicara dengan temannya. Masalah lain yang ditemukan pada saat observasi adalah penjelasan materi yang sering kali membutuhkan waktu yang terlalu lama untuk satu materi, dan kemampuan siswa dalam menjawab pertanyaan guru mengenai akuntansi yang masih didominasi oleh siswa tertentu.

Berdasarkan uraian di atas, peneliti ingin mengetahui pengaruh Pekerjaan Rumah dan Minat Belajar Akuntansi terhadap Prestasi Belajar Akuntansi. Oleh karena itu, peneliti tertarik untuk melakukan penelitian dengan judul "Pengaruh Pekerjaan Rumah dan Minat Belajar Akuntansi terhadap Prestasi Belajar Akuntansi Siswa Kelas $\quad X \quad$ Akuntansi SMK Negeri 7 Yogyakarta Tahun Ajaran 2015/2016". 


\section{METODE PENELITIAN \\ Jenis Penelitian}

Penelitian ini merupakan penelitian ex post facto. Penelitian ini juga termasuk penelitian kausal komparatif. Penelitian ini bertujuan untuk melihat pengaruh antara variabel $\mathrm{X}_{1}, \mathrm{X}_{2}$ terhadap $\mathrm{Y}$.

\section{Waktu dan Tempat Penelitian}

Penelitian ini dilaksanakan di SMK Negeri 7 Yogyakarta kelas $\mathrm{X}$ Jurusan Akuntansi. SMK Negeri 7 Yogyakarta berlokasi di Jalan Gowongan Kidul JT III/416 Yogyakarta. Penelitian ini dilaksanakan dari bulan Januari 2016 sampai dengan bulan Maret 2016 yang meliputi beberapa tahapan yaitu tahap persiapan, tahap pelaksanaan, dan tahap pelaporan.

\section{Populasi dan Sampel Penelitian}

Populasi dalam penelitian ini adalah seluruh siswa kelas $\mathrm{X}$ Akuntansi SMK Negeri 7 Yogyakarta Tahun Ajaran 2015/2016 yang berjumlah 96 siswa yang sekaligus sebagai sampel.

\section{Prosedur}

Penelitian ini merupakan penelitian populasi. Menurut Suharsimi Arikunto (2013: 95) “apabila jumlah anggota populasi kurang dari 100 hingga 150 orang, dan dalam pengumpulan data peneliti menggunakan angket, sebaiknya jumlah tersebut diambil seluruhnya". Berdasarkan pendapat tersebut, maka semua siswa kelas X Akuntansi SMK Negeri 7 Yogyakarta yang berjumlah 96 siswa dijadikan sebagai responden penelitian karena jumlahnya kurang dari 100. Oleh karena itu, penelitian ini merupakan penelitian populasi.
Data, Instrumen, dan Teknik Pengumpulan

a. Data

Teknik pengumpulkan data menggunakan angket dan dokumentasi. Angket digunakan untuk mengumpulkan data variabel Pekerjaan Rumah dan Minat Belajar Akuntansi. Dokumentasi digunakan untuk mengumpulkan data Prestasi Belajar Akuntansi.

b. Uji Instrumen Penelitian

Uji coba instrumen dilakukan pada siswa kelas X Akuntansi 1 SMK Negeri 1 Yogyakarta Tahun Ajaran 2015/2016 sejumlah 31 siswa. Instrumen akan dapat digunakan apabila instrumen memenuhi kriteria validitas dan reliablitas.

c. Uji Validitas

Rumus:

$$
\mathrm{r}_{\mathrm{XY}}=\frac{\mathrm{N} \sum \mathrm{XY}-\left(\sum \mathrm{X}\right)\left(\sum \mathrm{Y}\right)}{\sqrt{\left\{\mathrm{N} \sum \mathrm{X}^{2}-\left(\sum \mathrm{X}\right)^{2}\right\}\left\{\mathrm{N} \Sigma \mathrm{Y}^{2}-\left(\sum \mathrm{Y}\right)^{2}\right\}}}
$$

(Suharsimi, 2013: 213)

Hasil uji menunjukkan untuk angket Pekerjaan Rumah dari 23 butir pernyataan 4 pernyataan gugur dan 19 pernyataan valid, sedangkan untuk angket Minat Belajar Akuntansi dari 22 pernyataan, 2 pernyataan gugur dan 20 pernyataan valid.

d. Uji Reliabilitas

Rumus:

$$
\mathrm{r}_{\text {II }}=\left(\frac{\mathrm{k}}{\mathrm{k}-1}\right)\left(1-\frac{\sum \sigma^{2} \mathrm{~b}}{\sigma^{2} \mathrm{t}}\right)
$$

(Suharsimi, 2013: 239)

Hasil uji menunjukan reliabilitas instrumen Pekerjaan Rumah sebesar 0,839 (sangat kuat) dan instrumen Minat Belajar Akuntansi sebesar 0,871 (sangat kuat), sehingga kedua instrumen tersebut dapat dikatakan sudah reliabel. 
e. Teknik Analisis Data

1) Deskripsi data

Analisis deskriptif yang dilakukan meliputi: Mean, Median, Modus, Standar Deviasi, Nilai Maksimum, Nilai Minimum, Tabel Distribusi Frekuensi, Histogram, Tabel Kecenderungan Variabel, Pie Chart.

2) Uji Prasyarat Analisis

a) Uji Linieritas

Rumus:

$$
\text { Freg }=\frac{R K_{\text {reg }}}{R K_{\text {res }}}
$$

Sutrisno Hadi (2004: 13)

b) Uji Multikolinieritas

Rumus:

$$
r_{x y}=\frac{N \sum N Y-\left(\sum X\right)\left(\sum Y\right)}{\sqrt{\left\{N \sum X^{2}-\left(\sum X\right)^{2}\right\}}\left\{N \sum Y^{2}-\left(\sum Y\right)^{2}\right\}}
$$

(Suharsimi Arikunto, 2013: 213)

3) Uji Hipotesis

a) Analisi Regresi Sederhana

Analisis ini digunakan untuk menguji hipotesis ke-1 dan hipotesis ke-2.Rumus yang digunakan adalah sebagai berikut:

(1) Membuat Persamaan Garis Regresi Satu Prediktor, dengan rumus:

$\mathrm{Y}=\mathrm{aX}+\mathrm{K}$

Sutrisno Hadi (2004: 1)

(2) Mencari Koefisien korelasi sederhana

$\mathrm{r}_{\mathrm{xy}}=\frac{\sum x y}{\sqrt{\left(\Sigma x^{2}\right)\left(\Sigma y^{2}\right)}}$

(Sutrisno Hadi, 2004: 4)

(3) Mencari Koefisien Determinasi

$\mathrm{r}^{2}(1)=\frac{a_{1} \sum \mathrm{x}_{1} Y}{\Sigma y^{2}} \quad \mathrm{r}^{2}(2)=\frac{a_{2} \sum \mathrm{x}_{1} Y}{\Sigma y}$

Sutrisno Hadi (2004: 22)
(4) Menguji Signifikansi dengan uji t

$t=\frac{r(\sqrt{n-2})}{\left(\sqrt{1-r^{2}}\right)}$

Sugiyono (2009: 257)

b) Analisis Regresi Ganda

Analisis ini digunakan untuk menguji hipotesis ketiga. Langkah-langkah analisis regresi ganda meliputi:

(1) Membuat Persamaan Garis Regresi 2 Prediktor rumus:

$\mathrm{Y}=\mathrm{a}_{1} \mathrm{X}_{1}+\mathrm{a}_{2} \mathrm{X}_{2}+\mathrm{K}$

Sutrisno Hadi (2004: 18)

(2) Mencari koefisien korelasi (R)

$R y_{(1,2)}=\sqrt{\frac{a_{1} \sum_{X_{1} Y+a_{2} \Sigma_{X 2} Y}}{\Sigma_{y}^{2}}}$

(Sutrisno Hadi, 2004: 22)

(3) Mencari Koefisien Determinan

$\mathrm{R}_{\mathrm{y}(1,2)}^{2}=\frac{a_{1} \mathrm{x}_{1 \mathrm{Y}+} a_{2 \Sigma x_{2 \mathrm{Y}}}}{\Sigma y^{2}}$

Sutrisno Hadi (2004: 22)

(4) Menguji Signifikansi Regresi Ganda dengan Uji F menggunakan rumus:

$F_{\text {reg }}=\frac{R^{2}(N-m-1)}{m\left(1-R^{2}\right)}$

(Sutrisno Hadi, 2004: 23)

(5) Mencari Sumbangan Relatif (SR) dan Sumbangan Efektif (SE)

(a)Sumbangan Relatif (SR)

$$
\mathrm{SR} \%=\frac{a \Sigma x y}{J K_{\text {reg }}} \times 100 \%
$$

(Sutrisno Hadi, 2004:37)

(b) Sumbangan Efektif (SE)

$\mathrm{SE} \%=\mathrm{SR} \% \times \mathrm{R}^{2}$

(Sutrisno Hadi, 2004:39) 


\section{HASIL PENELITIAN DAN PEMBA- HASAN}

\section{Hasil Penelitian}

a. Deskripsi Data Penelitian

1) Prestasi Belajar Akuntansi

Berdasarkan analisis data yang dilakukan menggunakan SPSS Statistic, maka diperoleh nilai mean sebesar 82,82 , median sebesar 82, modus sebesar 81, standar deviasi sebesar 3,907, maksimum sebesar 91, dan minimum sebesar 76 .

Tabel 1. Distribusi Frekuensi Variabel Prestasi Belajar Akuntansi

\begin{tabular}{|c|c|c|}
\hline No. & Interval Kelas & Frekuensi \\
\hline 1 & $76-77$ & 4 \\
\hline 2 & $78-79$ & 13 \\
\hline 3 & $80-81$ & 25 \\
\hline 4 & $82-83$ & 23 \\
\hline 5 & $84-85$ & 10 \\
\hline 6 & $86-87$ & 7 \\
\hline 7 & $88-89$ & 3 \\
\hline 8 & $90-91$ & 11 \\
\hline \multicolumn{2}{|c|}{ Jumlah } & 96 \\
\hline
\end{tabular}

Sumber: Data Primer yang diolah

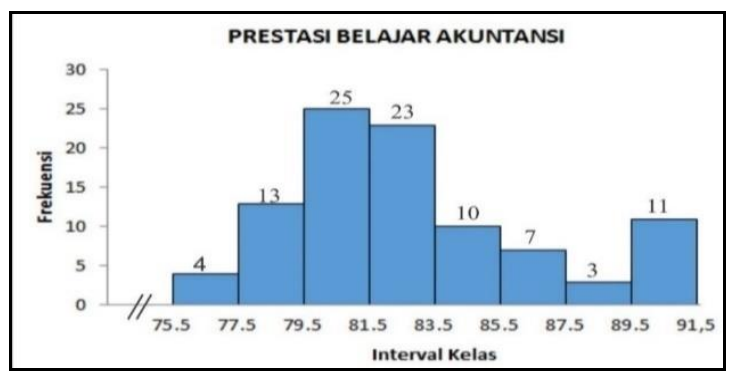

Gambar 1. Histogram Variabel Prestasi Belajar Akuntansi

Tabel 2. Kecenderungan Variabel Prestasi Belajar Akuntansi

\begin{tabular}{|l|l|l|l|l|}
\hline No & Nilai & $\mathbf{F}$ & $\mathbf{F ~ ( \% )}$ & Kategori \\
\hline 1 & $\geq 75$ & 96 & $100 \%$ & Tuntas \\
\hline 2 & $<75$ & 0 & $0 \%$ & BelumTuntas \\
\hline \multicolumn{2}{|l|}{ Total } & 96 & $100 \%$ & \\
\hline
\end{tabular}

Sumber: Data Primer yang diolah
PRESTASI BELAJAR AKUNTANSI

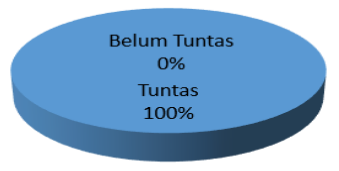

Tuntas

Belum Tuntas

Gambar 2. Pie Chart Variabel Prestasi Belajar Akuntansi

2) Pekerjaan Rumah

Berdasarkan analisis data yang dilakukan menggunakan SPSS Statistic, maka diperoleh nilai mean sebesar 62,02, median sebesar 62, modus sebesar 62, standar deviasi sebesar 4,408, maksimum sebesar 74, dan minimum sebesar 51.

Tabel 3. Distribusi Frekuensi Variabel Pekerjaan Rumah

\begin{tabular}{|c|c|c|}
\hline No. & Interval Kelas & Frekuensi \\
\hline 1 & $51-53$ & 3 \\
\hline 2 & $54-56$ & 9 \\
\hline 3 & $57-59$ & 13 \\
\hline 4 & $60-62$ & 26 \\
\hline 5 & $63-65$ & 26 \\
\hline 6 & $66-68$ & 13 \\
\hline 7 & $69-71$ & 5 \\
\hline 8 & $72-74$ & 1 \\
\hline \multicolumn{2}{|r|}{ Jumlah } & 96 \\
\hline
\end{tabular}

Sumber: Data Primer yang diolah

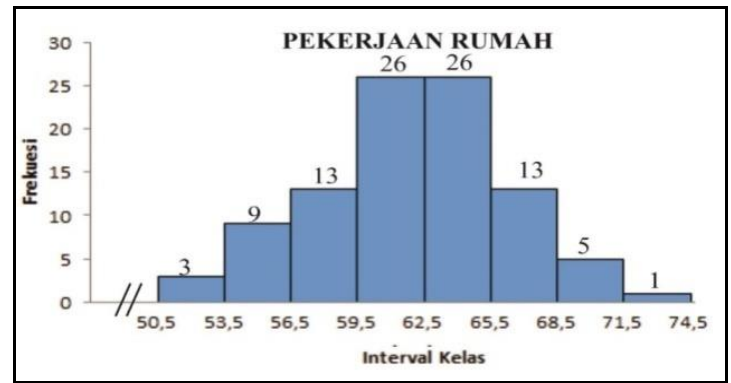

Gambar 3. Histogram Pekerjaan Rumah 
Tabel 4. Kecenderungan Variabel Pekerjaan Rumah

\begin{tabular}{|l|l|l|l|l|}
\hline No. & Skor & F & F(\%) & Kategori \\
\hline 1 & $>57$ & 82 & $85,42 \%$ & Sering \\
\hline 2 & $38-57$ & 14 & $14,58 \%$ & Cukup \\
\hline 3 & $<38$ & 0 & $0 \%$ & Kurang \\
\hline \multicolumn{2}{|c|}{ Jumlah } & 96 & $100 \%$ & \\
\hline
\end{tabular}

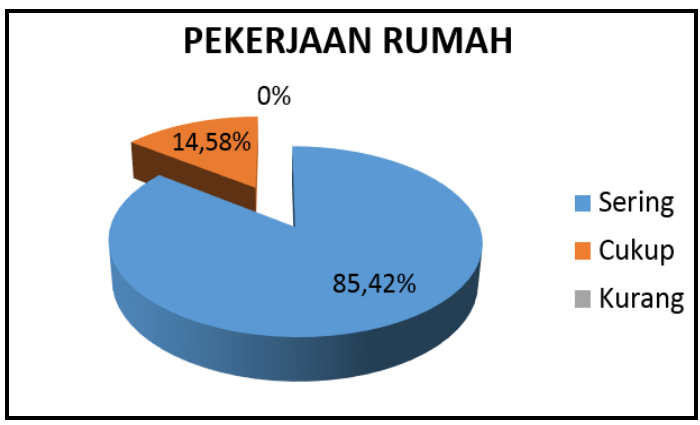

Gambar 4. Pie Chart Variabel Pekerjaan Rumah

3) Minat Belajar Akuntansi

Berdasarkan analisis data yang dilakukan menggunakan SPSS Statistic, maka diperoleh nilai mean sebesar 60,14, median sebesar 60, modus sebesar 60, standar deviasi sebesar 5,859, maksimum sebesar 73, dan minimum sebesar 42 .

Tabel 5. Distribusi Frekuensi variabel Minat Belajar Akuntansi

\begin{tabular}{|c|c|c|}
\hline No. & Interval Kelas & Frekuensi \\
\hline 1 & $42-45$ & 1 \\
\hline 2 & $46-49$ & 3 \\
\hline 3 & $50-53$ & 8 \\
\hline 4 & $54-57$ & 14 \\
\hline 5 & $58-61$ & 33 \\
\hline 6 & $62-65$ & 21 \\
\hline 7 & $66-69$ & 12 \\
\hline 8 & $70-73$ & 4 \\
\hline \multicolumn{2}{|c|}{ Jumlah } & 96 \\
\hline
\end{tabular}

Sumber: Data Primer yang Diolah

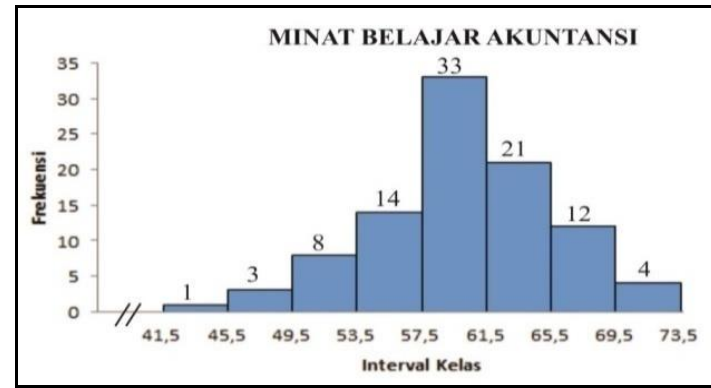

Gambar 5. Histogram Variabel Minat Belajar Akuntansi

Tabel 6. Kecenderungan Variabel Minat Belajar Akuntansi

\begin{tabular}{|c|c|c|c|c|}
\hline No. & Skor & $\mathbf{F}$ & $\mathbf{F}(\%)$ & Kategori \\
\hline 1 & $>60$ & 44 & $45,83 \%$ & Tinggi \\
\hline 2 & $40-60$ & 52 & $54,17 \%$ & Sedang \\
\hline 3 & $<40$ & 0 & $0 \%$ & Rendah \\
\hline \multicolumn{2}{|c|}{ Jumlah } & 96 & $100 \%$ & \\
\hline
\end{tabular}

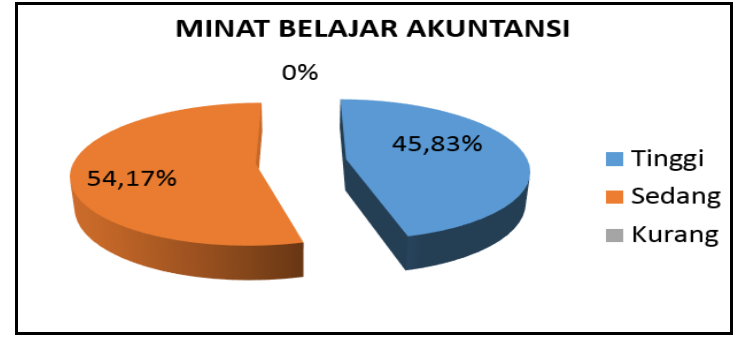

Gambar 6. Pie Chart Variabel Minat Belajar Akuntansi

b. Pengujian Persyaratan Analisis

1) Uji Linieritas

Tabel 7. Ringkasan Hasil Uji Linieritas

\begin{tabular}{|c|c|c|c|c|c|}
\hline No & \multicolumn{2}{|c|}{$\begin{array}{c}\text { Varia } \\
\text { bel }\end{array}$} & Fhitung & Ftabel & $\begin{array}{c}\text { Kesim } \\
\text { pulan }\end{array}$ \\
\hline 1. & $\mathrm{X}_{1}$ & $\mathrm{Y}$ & 1,684 & 1,741 & Linier \\
\hline 2. & $\mathrm{X}_{2}$ & $\mathrm{Y}$ & 0,780 & 1,682 & Linier \\
\hline
\end{tabular}

Sumber: Data Primer yang diolah.

2) Uji multikolinieritas

Tabel 8. Ringkasan Hasil Uji Multikolinieritas

\begin{tabular}{|l|l|l|l|}
\hline $\mathbf{V}$ & $\mathbf{X}_{\mathbf{1}}$ & $\mathbf{X}_{\mathbf{2}}$ & Keterangan \\
\hline $\mathrm{X}_{1}$ & 1 & 0,522 & Tidak Terjadi \\
multikolinieritas
\end{tabular}

Sumber: Data Primer yang diolah 
c. Uji Hipotesis

1) Uji Hipotesis Pertama

Tabel 9. Ringkasan Hasil Uji Hipotesis Pertama

\begin{tabular}{|l|l|l|}
\hline Keterangan & Nilai & \multirow{2}{*}{ Kesimpulan } \\
\hline $\mathbf{r}_{\mathrm{x} 1 \mathrm{y}}$ & 0,361 & Positif \\
\cline { 1 - 2 } $\mathbf{r}^{2}{ }_{\mathrm{x} 1 \mathrm{y}}$ & 0,131 & \multirow{3}{*}{ Signifikan } \\
\hline$t_{\text {hitung }}$ & 3,759 & \\
\hline$t_{\text {tabel }}$ & 1,66123 & \\
\cline { 1 - 2 } Koefisien & 0,320 & \\
\cline { 1 - 2 } Konstanta & 62,954 & \\
\hline
\end{tabular}

Sumber: Data Primer yang diolah

Berdasarkan hasil di atas maka dapat disimpulkan bahwa hipotesis pertama yaitu terdapat pengaruh positif Pekerjaan Rumah terhadap Prestasi Belajar Akuntansi Siswa Kelas $\mathrm{X}$ Akuntansi SMK Negeri 7 Yogyakarta Tahun Ajaran 2015/2016 didukung oleh penelitian ini.

2) Uji Hipotesis Kedua

Tabel 10. RingkasanUji Hipotesis Kedua

\begin{tabular}{|l|l|l|}
\hline Keterangan & Nilai & Kesimpulan \\
\hline$r_{\mathrm{x} 2 \mathrm{y}}$ & 0,376 & Positif \\
\cline { 1 - 2 } $\mathrm{r}_{\mathrm{x} 2 \mathrm{y}}$ & 0,142 & \multirow{2}{*}{ Signifikan } \\
\cline { 1 - 1 } $\mathrm{t}_{\mathrm{i} \text { itung }}$ & 3,938 & \\
\cline { 1 - 2 } $\mathrm{t}_{\text {tabel }}$ & 1,66123 & \\
\cline { 1 - 2 } Koefisien & 0,251 & \\
\cline { 1 - 2 } Konstanta & 67,734 & \\
\hline
\end{tabular}

Sumber: Data Primer yang diolah

Berdasarkan hasil di atas maka dapat disimpulkan bahwa hipotesis kedua yaitu terdapat pengaruh positif Minat Belajar Akuntansi terhadap Prestasi Belajar Akuntansi Siswa Kelas X Akuntansi SMK Negeri 7 Yogyakarta Tahun Ajaran 2015/2016 didukung oleh penelitian ini.
3) Uji Hipotesis Ketiga

Tabel 11. Ringkasan Uji Hipotesis Ketiga

\begin{tabular}{|c|c|c|}
\hline Keterangan & Nilai & Kesimpulan \\
\hline $\mathrm{R}_{\mathrm{y}(1,2)}$ & 0,423 & \multirow{7}{*}{$\begin{array}{l}\text { Positif } \\
\text { Signifikan }\end{array}$} \\
\hline $\mathrm{R}_{\mathrm{y}(1,2)}^{2}$ & 0,179 & \\
\hline Fhitung & 10,144 & \\
\hline$F_{\text {tabel }}$ & 3,09 & \\
\hline Koefisien $\mathrm{X}_{1}$ & 0,201 & \\
\hline Koefisien $\mathrm{X}_{2}$ & 0,172 & \\
\hline Konstanta & 60,007 & \\
\hline
\end{tabular}

Sumber: Data Primer yang diolah

Berdasarkan hasil di atas maka dapat disimpulkan bahwa hipotesis ketiga yaitu terdapat pengaruh positif Pekerjaan Rumah dan Minat Belajar Akuntansi secara bersama-sama terhadap Prestasi Belajar Akuntansi Siswa Kelas X Akuntansi SMK Negeri 7 Yogyakarta Tahun Ajaran 2015/2016 didukung oleh penelitian ini.

Besarnya sumbangan relatif dan sumbangan efektif sebagai berikut:

Tabel 12. Ringkasan Hasil Sumbangan Relatif dan Sumbangan Efektif

\begin{tabular}{|l|l|l|l|}
\hline Ket. & $\mathbf{X}_{\mathbf{1}}$ & $\mathbf{X}_{\mathbf{2}}$ & Jumlah \\
\hline SR\% & $54,64 \%$ & $45,36 \%$ & $100 \%$ \\
\hline SE\% & $9,78 \%$ & $8,12 \%$ & $17,9 \%$ \\
\hline
\end{tabular}

Sumber: Data Primer yang diolah

Berdasarkan hasil analisis yang tercantum dalam tabel di atas dapat diketahui bahwa Pekerjaan Rumah memberikan sumbangan relatif sebesar 54,64\% dan Minat Belajar Akuntansi sebesar 45,36\%. Sumbangan efektif total sebesar $17,9 \%$ yang berarti variabel Pekerjaan Rumah dan Minat Belajar Akuntansi secara bersama- sama memberikan sumbangan efektif sebesar $17,9 \%$, sedangkan $82,1 \%$ diberikan oleh variabel- variabel lain yang tidak dibahas dalam penelitian ini. 


\section{PEMBAHASAN}

a. Pengaruh Pekerjaan Rumah terhadap Prestasi Belajar Akuntansi

Hasil Penelitian menunjukkan bahwa nilai koefisien korelasi $r_{x 1 y}$ sebesar 0,361 dan koefisien determinasi $r^{2} x 1 y$ sebesar 0,131 . Hal ini menunjukkan bahwa terdapat pengaruh positif Pekerjaan Rumah terhadap Prestasi Belajar Akuntansi yang bermakna bahwa semakin sering Pekerjaan Rumah maka akan semakin tinggi pula Prestasi Belajar Akuntansi siswa kelas X Akuntansi SMK Negeri 7 Yogyakarta Tahun Ajaran 2015/2016, begitupun sebaliknya. Setelah dilakukannya Uji Signifikansi dengan Uji t didapatkan nilai thitung sebesar 3,759, kemudian dibandingkan dengan nilai tabel pada taraf signifikansi sebesar 5\% yaitu sebesar 1,66123 maka thitung $>$ tabel sehingga variabel Pekerjan Rumah memberikan pengaruh yang signifikan terhadap Prestasi Belajar Akuntansi Siswa. Kesimpulan yang dapat diambil dari analisis ini adalah terdapat pengaruh positif dan signifikan Pekerjaan Rumah terhadap Prestasi Belajar Akuntansi Siswa Kelas X Akuntansi SMK Negeri 7 Yogyakarta Tahun Ajaran 2015/2016.

Hasil penelitian ini diperkuat oleh pendapat dari beberapa ahli dalam kajian teori mengenai faktor-faktor yang dapat mempengaruhi Prestasi Belajar Akuntansi Siswa salah satunya adalah faktor eksternal yaitu Pekerjaan Rumah (PR). Pekerjaan Rumah adalah pemberian tugas-tugas oleh guru kepada siswa sebagai selingan yang merupakan variasi dari teknik penyajian materi kepada siswa atau pemberian suatu pekerjaan yang diberikan oleh guru kepada siswanya untuk diselesaikan di rumah. Daniel Muijs dan David Reynolds (2008: 150) menyatakan bahwa salah satu tujuan pemberian Pekerjaan Rumah adalah untuk meningkatkan prestasi murid.

Hasil penelitian ini selaras juga dengan penelitian yang dilakukan oleh Puspita Dewi Wulaningrum pada tahun 2012 dengan judul "Pengaruh Persepsi Siswa tentang Mata Pelajaran Akuntansi dan Pemberian Pekerjaan Rumah terhadap Prestasi Belajar Akuntansi Siswa Kelas XI IPS SMA Negeri 1 Sewon Tahun Ajaran 2011/2012”. Hasil penelitian ini adalah terdapat pengaruh positif dan signifikan Pemberian Pekerjaan Rumah terhadap Prestasi Belajar Akuntansi yang dibuktikan dengan $r_{x 2 y}=0,434, r_{x 2 y}^{2}=$ $0,188, p$-value $=0,000$, thitung $>$ tabel $(4,689$ $>1,985)$.

Berdasarkan pendapat dan hasil penelitian tersebut dapat disimpulkan bahwa semakin sering Pekerjaan Rumah maka akan semakin tinggi pula Prestasi Belajar Akuntansi siswa dan sebaliknya jika Pekerjaan Rumah kurang maka semakin rendah Prestasi Belajar Akuntansi yang diperoleh oleh siswa. Adanya Pekerjaan Rumah akan membuat siswa berlatih mendalami pengetahuan yang didapatkannya di kelas. Pemberian Pekerjaan Rumah juga akan mendorong siswa agar mau belajar lebih giat dengan mengerjakan soal-soal atau tugas yang harus dikerjakan. Hal ini akan membantu siswa dalam memperoleh Prestasi Belajar Akuntansi yang optimal. Guru dalam memberikan Pekerjaan Rumah harus mempertimbangkan beberapa hal seperti kesesuaian Pekerjaan Rumah yang diberikan oleh guru dengan materi pelajaran, frekuensi pemberian Pekerjaan Rumah oleh guru, pengerjaan Pekerjaan Rumah oleh siswa, pembahasan Pekerjaan Rumah oleh guru , dan feedback berupa nilai PR yang diberikan oleh guru sehingga pemberian Pekerjaan Rumah tersebut akan efektif dalam 
membantu siswa mencapai Prestasi Belajar Akuntansi yang optimal.

b. Pengaruh Minat Belajar Akuntansi terhadap Prestasi Belajar Akuntansi

Hasil Penelitian menunjukkan bahwa nilai koefisien korelasi $r_{x 2 y}$ sebesar 0,376 dan koefisien determinasi $r^{2}{ }_{x 2 y}$ sebesar 0,142 . Hal ini menunjukkan bahwa terdapat pengaruh positif Minat Belajar Akuntansi terhadap Prestasi Belajar Akuntansi yang bermakna bahwa semakin tinggi Minat Belajar Akuntansi maka akan semakin tinggi pula Prestasi Belajar Akuntansi siswa kelas X Akuntansi SMK Negeri 7 Yogyakarta Tahun Ajaran 2015/2016, begitupun sebaliknya. Setelah dilakukannya Uji Signifikansi dengan Uji t didapatkan nilai thitung sebesar 3,938, kemudian dibandingkan dengan nilai tabel pada taraf signifikansi sebesar 5\% yaitu sebesar 1,66123 maka $t_{\text {hitung }}>t_{\text {tabel }}$ sehingga variabel Minat Belajar Akuntansi memberikan pengaruh yang signifikan terhadap Prestasi Belajar Akuntansi. Kesimpulan yang dapat diambil dari analisis ini adalah terdapat pengaruh positif dan signifikan Minat Belajar Akuntansi terhadap Prestasi Belajar Akuntansi Siswa Kelas X Akuntansi SMK Negeri 7 Yogyakarta Tahun Ajaran 2015/2016.

Hasil penelitian ini diperkuat oleh pendapat dari beberapa ahli dalam kajian teori mengenai faktor-faktor yang dapat mempengaruhi Prestasi Belajar Akuntansi salah satunya adalah faktor internal yaitu Minat Belajar Akuntansi. Minat belajar merupakan keinginan yang datang dari diri siswa untuk ikut serta dalam kegiatan belajar. Seorang siswa yang mempunyai minat belajar yang tinggi cenderung untuk mempunyai prestasi belajar yang tinggi. Hal ini sejalan dengan pendapat dari Dalyono (2005: 57) yang mengemukakan bahwa minat belajar yang besar cenderung menghasilkan prestasi yang tinggi, sebaliknya minat belajar yang kurang akan menghasilkan prestasi belajar yang rendah.

Hasil penelitian ini selaras juga dengan penelitian yang dilakukan oleh Sri Nur Selviana pada tahun 2012 dengan judul "Pengaruh Minat Belajar dan Pemanfaatan Waktu Belajar Siswa di Luar Jam Pelajaran terhadap Prestasi Belajar Akuntansi Keuangan Siswa Kelas XI Kompetensi Keahlian Akuntansi SMK Negeri 1 Yogyakarta Tahun Ajaran 2012/2013". Hasil penelitian ini adalah terdapat pengaruh positif dan signifikan Minat Belajar terhadap Prestasi Belajar Akuntansi Keuangan Siswa Kelas XI Kompetensi Keahlian Akuntansi SMK Negeri 1 Yogyakarta Tahun Ajaran 2012/2013. Hal ini ditunjukkan dengan harga $r_{x l y}$ sebesar $0,739, r^{2}$ xly sebesar 0,533 , harga thitung sebesar 8,482 lebih besar dari tabel 1,997 pada taraf signifikansi 5\% dan persamaan regresi sederhana yakni $\mathrm{Y}=$ $0,495 \mathrm{X}_{1}+49,365$.

Berdasarkan pendapat dan hasil tersebut dapat disimpulkan bahwa semakin tinggi Minat Belajar Akuntansi yang dimiliki oleh siswa maka akan semakin tinggi pula Prestasi Belajar Akuntansi yang diperoleh siswa dan sebaliknya jika Minat Belajar Akuntansi rendah maka akan semakin rendah Prestasi Belajar Akuntansi yang diperoleh oleh siswa.

c. Pengaruh Pekerjaan Rumah dan Minat Belajar Akuntansi secara bersama-sama terhadap Prestasi Belajar Akuntansi

Hasil Penelitian menunjukkan bahwa nilai koefisien korelasi $\left(\mathrm{R}_{\mathrm{y}(1,2)}\right)$ sebesar 0,423 dan koefisien determinasi $\left(\mathrm{R}_{\mathrm{y}(1,2))}\right.$ 
sebesar 0,179 . Hal ini menunjukkan bahwa terdapat pengaruh positif Pekerjaan Rumah dan Minat Belajar Akuntansi secara bersama-sama terhadap Prestasi Belajar Akuntansi yang bermakna bahwa semakin sering Pekerjaan Rumah dan semakin tinggi Minat Belajar Akuntansi maka akan semakin tinggi pula Prestasi Belajar Akuntansi siswa kelas $\mathrm{X}$ Akuntansi SMK Negeri 7 Yogyakarta Tahun Ajaran 2015/2016, begitupun sebaliknya. Setelah dilakukannya Uji Signifikansi dengan Uji F didapatkan nilai $F_{\text {hitung }}$ sebesar 10,144, kemudian dibandingkan dengan nilai $\mathrm{F}_{\text {tabel }}$ pada taraf signifikansi sebesar 5\% yaitu sebesar 3,09 maka $\quad F_{\text {hitung }}>\mathrm{F}_{\text {tabel }}$ sehingga variabel Pekerjaan Rumah dan Minat Belajar Akuntansi secara bersama-sama memberikan pengaruh yang signifikan terhadap Prestasi Belajar Akuntansi. Kesimpulan yang dapat diambil dari analisis ini adalah terdapat pengaruh positif dan signifikan Pekerjaan Rumah dan Minat Belajar Akuntansi secara bersama-sama terhadap Prestasi Belajar Akuntansi Siswa Kelas $\quad X \quad$ Akuntansi SMK Negeri 7 Yogyakarta Tahun Ajaran 2015/2016. Sumbangan Relatif (SR) variabel Motivasi Belajar sebesar 37,23\% dan variabel Status Ekonomi Keluarga sebesar $62,77 \%$, total yang diperoleh dari Sumbangan Relatif (SR) sebesar 100\%. Sumbangan Efektif (SE) variabel Pekerjaan Rumah sebesar 9,78\% dan variabel Minat Belajar Akuntansi sebesar $8,12 \%$. Total Sumbangan Efektif (SE) kedua variabel ialah sebesar $17,9 \%$, dan sebesar $82,1 \%$ diberikan oleh variabel lain yang tidak diteliti dalam penelitian ini.

Hasil penelitian ini diperkuat oleh pendapat dari beberapa ahli dalam kajian teori mengenai faktor-faktor yang dapat mempengaruhi Prestasi Belajar Akuntansi
Siswa yang terdiri dari faktor internal dan faktor eksternal. Faktor internal yang dapat mempengaruhi Prestasi Belajar Akuntansi salah satunya adalah Minat Belajar Akuntansi Siswa, sedangkan faktor eksternal yang dapat mempengaruhi Prestasi Belajar Akuntansi adalah Pekerjaan Rumah. Pekerjaan Rumah menjadi faktor dari luar yang membantu siswa dalam mencapai prestasi yang diinginkan dan Minat Belajar Akuntansi menjadi faktor dari dalam diri siswa itu sendiri untuk mencapai prestasi yang diinginkan.

Kedua faktor ini mempunyai pengaruh yang positif dan signifikan secara bersamasama terhadap Prestasi Belajar Akuntansi sehingga perlu adanya perhatian baik dari guru, siswa maupun pihak sekolah. Jika pemberian Pekerjaan Rumah dilakukan secara baik dan sering disertai dengan Minat Belajar Akuntansi yang tinggi maka Prestasi Belajar Akuntansi siswa juga akan tinggi. Berkaitan dengan hal ini, maka guru sebagai pengajar harus memberikan Pekerjan Rumah yang baik yang dapat meningkatkan Prestasi Belajar Akuntansi siswa serta sebisa mungkin untuk menumbuhkan, mengembangkan dan meningkatkan Minat Belajar Akuntansi Siswa.

Hasil penelitian ini selaras juga dengan penelitian yang dilakukan oleh Puspita Dewi Wulaningrum pada tahun 2012 dengan judul "Pengaruh Persepsi Siswa tentang Mata Pelajaran Akuntansi dan Pemberian Pekerjaan Rumah terhadap Prestasi Belajar Akuntansi Siswa Kelas XI IPS SMA Negeri 1 Sewon Tahun Ajaran 2011/2012" yang menunjukkan bahwa terdapat pengaruh positif dan signifikan Pemberian Pekerjaan Rumah terhadap Prestasi Belajar Akuntansi yang dibuktikan dengan $r_{x 2 y}=0,434, r_{x 2 y}^{2}=$ $0,188, \quad p$-value $=0,000, \quad$ thitung $>$ tabel 
$(4,689>1,985)$. Hasil penelitian ini juga selaras dengan penelitian yang dilakukan oleh Sri Nur Selviana pada tahun 2012dengan judul "Pengaruh Minat Belajar dan Pemanfaatan Waktu Belajar Siswa di Luar Jam Pelajaran terhadap Prestasi Belajar Akuntansi Keuangan Siswa Kelas XI Kompetensi Keahlian Akuntansi SMK Negeri 1 Yogyakarta Tahun Ajaran 2012/2013" yang menunjukkan bahwa terdapat pengaruh positif dan signifikan Minat Belajar terhadap Prestasi Belajar Akuntansi Keuangan Siswa Kelas XI Kompetensi Keahlian Akuntansi SMK Negeri 1 Yogyakarta Tahun Ajaran 2012/2013. Hal ini ditunjukkan dengan harga $r_{x l y}$ sebesar $0,739, r^{2}$ xly sebesar 0,533 , harga thitung sebesar 8,482 lebih besar dari tabel 1,997 pada taraf signifikansi 5\% dan persamaan regresi sederhana yakni $\mathrm{Y}=$ $\left.0,495 \mathrm{X}_{1}+49,365\right)$.

\section{SIMPULAN DAN SARAN}

\section{Simpulan}

Terdapat pengaruh positif dan signifikan Pekerjaan Rumah dan Minat Belajar Akuntansi secara bersama-sama terhadap Prestasi Belajar Akuntansi Siswa Kelas X Akuntansi SMK Negeri 7 Yogyakarta Tahun Ajaran 2015/2016, yang ditunjukkan dengan harga koefisien korelasi $\mathrm{R}_{\mathrm{y}(1,2)}$ sebesar 0,423 , dan harga koefisien determinasi $\mathrm{R}_{\mathrm{y}(1,2)}^{2}$ sebesar 0,179 , dengan persamaan garis regresi $\mathrm{Y}=0,201 \mathrm{X}_{1}+0,172 \mathrm{X}_{2}+60,007$, dan nilai $F_{\text {hitung }}$ lebih besar dari $F_{\text {tabel }}$ yaitu: $10,144>3,09$ pada taraf signifikan $5 \%$.

\section{Saran}

a. Guru sebaiknya lebih sering dalam memberikan nilai untuk setiap Pekerjaan Rumah yang dikerjakan oleh siswa dan guru memberitahukan nilai Pekerjaan Rumah yang diperoleh oleh siswa tersebut. Bagi siswa sendiri, diharapkan bertanya kepada guru tentang nilai Pekerjaan Rumah yang mereka dapatkan apabila guru sering tidak memberitahukan nilai Pekerjaan Rumah siswa.

b. Guru dapat memberikan tambahan tugas atau Pekerjaan Rumah kepada siswa yang diambilkan dari buku yang ada di perpustakaan sekolah. Selain itu, guru juga dapat meminta siswa untuk mempelajari materi yang ada di buku akuntansi yang ada di perpustakaan sekolah untuk kemudian mengadakan kuis sehingga siswa memperoleh referensi baru dengan meminjam buku akuntansi di perpustakaan.

\section{DAFTAR PUSTAKA}

Dalyono. (2005). Belajar dan Faktor-Faktor yang Mempengaruhinya. Jakarta: PT Rineka Cipta.

Muijs, Daniel, \& Reynolds, David. (2008). Effective teaching: Teoridan Aplikasi. Yogyakarta: PustakaPelajar.

Purwanti. (2012). "Pengaruh Minat Belajar dan Lingkungan Sebaya terhadap Prestasi Belajar Akuntansi Siswa kelas XI IPS SMA Negeri 1 Lendah Tahun Ajaran 2011/2012”.Skripsi. Yogyakarta: Universitas Negeri Yogyakarta.

Puspita Dewi Wulaningrum. (2012). "Pengaruh Persepsi Siswa tentang Mata Pelajaran Akuntansi dan Pemberian Pekerjaan rumah terhadap Prestasi Belajar Akuntansi Siswa kelas XI IPS SMA Negeri 1 


Sewon Tahun Ajaran

2011/2012".Skripsi. Yogyakarta:

Universitas Negeri Yogyakarta.

Slameto. (2010). Belajar dan Faktor-faktor yang Mempengaruhinya. Jakarta: PT Rineka Cipta.

Sri Nur Selviana. (2013). "Pengaruh Minat Belajar dan Pemanfaatan Waktu Belajar Siswa di Luar Jam Pelajaran terhadap Prestasi Belajar Akuntansi Keuangan Siswa Kelas XI Kompetensi Keahlian Akuntansi SMK Negeri 1 Yogyakarta Tahun Ajaran 2012/2013”. Skripsi. Yogyakarta: Universitas Negeri Yogyakarta.

Sugihartono, dkk. (2012). Psikologi

Pendidikan. Yogyakarta: UNY

Press.

Sugiyono. (2009). Metode Penelitian Pendidikan. Bandung:

ALFABETA.

Suharsimi Arikunto. (2013). Prosedur Penelitian Suatu Pendekatan Praktik. Jakarta: PT Rineka Cipta (2013). Manajemen Penelitian. Jakarta: PT Rineka Cipta.

Suprijanto. (2007). Pendidikan Orang Dewasa: Dari Teori Hingga Aplikasi. Jakarta: PT BumiAksara

Sutrisno Hadi. (2004). Analisis Regresi. Yogyakarta: ANDI. 